\title{
ГРУПОВЕ НАВЧАННЯ ЯК ЗАСІБ ФОРМУВАННЯ НАВИЧОК САМОКОНТРОЛЮ УЧНІВ ПОЧАТКОВИХ КЛАСІВ
}

Талаш I. О. Групове навчання як засіб формування навичок самоконтролю учнів початкових класів.

У статті розкриті особливості організації групової навчальної діяльності молодших школярів на уроках української мови, узагальнені психолого-педагогічні умови формування навичок самоконтролю учнів у процесі групової роботи, а також подано зразки вправ і завдань, що можуть бути використані вчителям початкової школи на уроках української мови для організації групової навчальної діяльності дітей.

Ключові слова: молодший шкільний вік, групова навчальна діяльність, навичка, самоконтроль, функції самоконтролю.

Талаш И. А. Групповое обучение как средство формирования навыков самоконтроля учеников начальной школы.

В статье раскрыты особенности организации групповой учебной деятельности младших школьников на уроках украинского языка, обобщены психологопедагогические условия формирования навыков самоконтроля учеников в процессе групповой работы, а также поданы образцы упражнений и заданий, которые могут быть использованы учителями начальной школы на уроках украинского языка для организации групповой учебной деятельности детей.

Ключевые слова: младший школьный возраст, групповая учебная деятельность, навык, самоконтроль, функции самоконтроля.

Talash I. O. Group learning as a means of formation of self-control skills of primary school pupils.

The article describes the peculiarities of organization of a group learning activity of primary school children at the lessons of Ukrainian language, generalized psychological and pedagogical conditions of formation of self-control skills of pupils in a group activity, and submitted samples of exercises and tasks that can be used by primary school teachers at the lessons of Ukrainian language for organization of group learning activities of children.

Key words: primary school age, group learning activity, skill, self-control, selfmonitoring functions.

Реформи, що відбуваються в сучасній освіті, зокрема й початковій, орієнтують учителів на впровадження інноваційних технологій, що створюватимуть сприятливі умови для формування гармонійної всебічно розвиненої особистості, здатної навчатися протягом життя, швидко орієнтуватися в інформаційному суспільстві та ефективно адаптуватися до сучасного соціуму. Слід зазначити, що будь-який аспект складної багатогранної життєдіяльності людини (C) І. О. Талаш, 2014. 
передбачає самоконтроль, адже він в остаточному підсумку $є$ дією із зіставлення уявлення про майбутню дію 3 безпосередньо даним зразком. Сенситивним періодом для формування навичок самоконтролю є молодший шкільний вік, оскільки саме в цей період активно формуються всі вольові якості особистості. Однією 3 оптимальних форм роботи на уроці, що дає змогу ефективно формувати навички самоконтролю, є групова навчальна діяльність. Вона забезпечує максимальну самостійність кожного учня у процесі виконання навчальних завдань під опосередкованим керівництвом вчителя, спонукає школярів уважніше ставитися до процесу й результатів своєї діяльності, перевіряючи кінцевий результат із поставленою метою, зі зразком. Однак, учителі початкової школи спорадично використовують групову навчальну діяльність на уроках, оскільки відчувають утруднення через недостатню кількість методичних розробок із формування навичок самоконтролю в учнів початкової школи засобом групового навчання.

Найбільший інтерес до групових форм навчальної діяльності спостерігається останні два десятиріччя. Загальні принципи організації групової навчальної діяльності висвітлені в працях Є. Божович, Н. Волкова, Т. Головань, В. Дяченко, В. Котова, Г. Цукерман, О. Ярошенко та ін.; дидактичні питання організації групової навчальної діяльності молодших розроблено в працях В. Вихрущ, І. Вістовської, Є. Задої, К. Нор, Н. Побіченко, О. Савченко, С. Танцорова, І. Чередова.

Дані психолого-педагогічних досліджень В. Рижик, І. Страхова, В. Чебишева, I. Якиманської, які вказують на здатність учнів молодшого шкільного віку свідомо регулювати свою діяльність, та дані досліджень у галузі нейропсихології й нейрофізіології про визрівання і функціонування структур головного мозку, що вказують на розвиток регулюючого гальмівного контролю кори головного мозку над інстинктивними й емоційними реакціями, дають змогу стверджувати, що на початок навчання створюються всі оптимальні умови для формування довільної регуляції власної діяльності. I хоч психофізіологічні особливості дитини молодшого шкільного віку $є$ підгрунтям для формування навичок самоконтролю, однак, як свідчать численні дослідження науковців, без спеціально створених педагогічних умов вони не будуть сформовані. Такими спеціальними педагогічними умовами можна розглядати організацію груповою навчальної діяльності школярів на уроках у початковій школі. 
У статті зроблено спробу проаналізувати й узагальнити психолого-педагогічні умови формування навичок самоконтролю в молодших школярів у процесі групової навчальної діяльності, а також розробити зразки вправ і завдань для організації групової роботи на уроках української мови.

Особливе місце у структурі навчальної діяльності посідають дії самоконтролю, що мають специфічні функції: вони спрямовані на саму діяльність (регулятивна і плануюча функції), фіксують ставлення учнів до себе як до суб'єкта цієї діяльності (перевірна, контрольнооцінна та корекційна функції), унаслідок чого їх спрямованість на розв'язання навчального завдання має опосередкований характер, під час самоконтролю особистість здійснює розумові та практичні дії, спрямовані на самооцінку, коригування та вдосконалення виконуваної роботи, оволодіває відповідними знаннями та вміннями. Формування самоконтролю тісно пов'язане з розвитком мислення, пам'яті, уваги й інших психічних процесів.

Для формування в учнів самоконтролю в навчальній діяльності, необхідно створити певні умови. Так, М. Боришевський вважає, що необхідними психологічними умовами, які відіграють значний вплив на становлення самоконтролю в навчальній діяльності школярів, $є$ позитивні мотиви. Автор виділяє такі мотиви: мотиви, пов'язані 3 особою вчителя; мотиви, пов'язані зі своїми навчальними інтересами; мотиви, визначені прагненням дістати винагороду або уникнути можливого покарання; мотиви, грунтовані на задоволенні інтересів учнівського колективу. М. Боришевський зазначає, що основою становлення самоконтролю можуть бути різні мотиви, однак важливим внутрішнім спонуканням до самоконтролю в молодших школярів є повага до вчителя, готовність виконувати будь-які вимоги вчителя, адже він $є$ референтною особою для дитини.

Аналіз наукових досліджень, присвячених проблемі формуванню самоконтролю дітей молодшого шкільного віку (М. Боришевьсикй, О. Зак, Н. Камишева, А. Линда, Т. Матіс, Г. Нікіфоров та ін.), дав змогув викоремити такі параметри, що впливають на формування самоконтролю учнів у навчальній діяльності: 1) свідоме підпорядкування власної діяльності правилам, вимогам, що сприяють визначенню способу дії; 2) орієнтування на задану систему вимог під час виконання будь-якої діяльності; 3) усвідомлене та поетапне виконання інструкцій; 4) самостійне виконання завдання за зразком, 
що сприймається візуально; 5) усвідомлення необхідності контролю за власною діяльністю.

Серед інших рис молодших школярів, що безпосередньо впливають на розвиток самоконтролю, слід також назвати їх підвищену емоційність, яка може виявлятися в різних формах. Одні діти надмірно рухливі, непосидючі, постійно прагнуть висловлювати власні здивування, обурення враження. Їм важко контролювати себе. Інші, навпаки, є надто вразливими, найменші неудачі пригнічують їх, вони стають замкненими тощо. Ці вікові й індивідуальні особливості психічного розвитку, емоційної сфери молодших школярів певним чином впливають на їхню навчальну діяльність $i$ розвиток самоконтролю. Причому, якщо в 1-2 класі школярі здійснюють контроль над навчальними діями головним чином за вказівкою дорослих, зокрема й учителя, то вже в 3 класі вони набувають здатності здійснювати контрольні дії відповідно до власних мотивів.

За спостереженнями А. Сердюк, самоконтроль у першокласників, особливо на початку навчального року, посідає незначне місце. Учні ще погано розуміють його роль, віддають перевагу над ними контролю 3 боку дорослих. Однак у третьому класі ставлення учнів до самоконтролю помітно змінюється: вони опановують певні прийоми його здійснення і виявляють розуміння його значення як засобу попередження помилок, кращого засвоєння навчального матеріалу. На ефективність такого переходу визначальний вплив має характер мотивації. Учень починає більш упевнено й, головне, самостійно контролювати власні дії, якщо вчителеві вдалося виховати в ньому правильне розуміння самоконтролю як необхідної умови успішності навчальної діяльності.

Одним із ефективних засобів формування навичок самоконтролю молодших школярів є групове навчання. У психолого-педагогічній літературі вироблено єдиний підхід до визначення групової навчальної діяльності. Е. Нор вважає, що групова навчальна діяльність - це форма організації навчання в малих групах учнів, об'єднаних загальною навчальною метою при опосередкованому керівництві вчителя й співпраці з учнями [2, с. 29]. О. Савченко уточнює подану Е. Нор дефініцію i визначає групову навчальну діяльність як форму організації навчання в малих групах на основі співробітництва 3 чітко розподіленими завданнями для учнів, об’єднаних навчальною метою, сприяє формуванню вмінь співпрацювати, спілкуватися [3, с. 35]. 
Психолого-педагогічні дослідження свідчать, що групова навчальна діяльність сприяє активізації й результативності навчання школярів, вихованню гуманних стосунків між ними, самостійності, формуванню вмінь доводити і відстоювати свою позицію, а також учить бути толерантними до думки товаришів, культурі ведення дискусії, відповідальному ставленню до результатів своєї праці.

Організовуючи групову навчальну діяльність на занятті, потрібно забезпечити активність кожного учня. Об'єднуючи дітей в групи, необхідно враховувати індивідуальні особливості школярів, слабкому учневі добирати не просто партнера, що гарно встигає, а терплячого, сумлінного учня, який в доступній формі зможе пояснити незрозуміле; роботу учнів в одній групі слід оцінювати об'єктивно, внесок кожного члена групи в спільну справу виявляється через само оцінювання й взаємооцінювання; оцінюючи роботу групи насамперед треба враховувати особисті якості учнів, а вже потім - навчальні; під час спільної діяльності не варто вимагати абсолютної тиші: діти мають обмірковувати відповідь на запитання, висловлювати свої думки, міркування; треба тільки шляхом переконання боротися 3 викриками й розмовами на повний голос.

Організовуючи групову діяльність на занятті, учитель повинен дотримуватися таких вимог: 1) чітко формулювати пізнавальні завдання; 2) завдання мають бути проблемними, спонукати учнів до активності, до творчого мислення, до пошуку нових знань і нових способів дій; 3) уважно спостерігати за ходом навчальної діяльності в малих групах; 4) зосередити увагу на діяльності слабких учнів; 5) заздалегідь інструктувати ланкових, спрямовуючи їх роботу в групі; 6) не створювати ситуації змагання на швидкість виконання завдання.

У процесі групової навчальної діяльності навички самоконтролю доцільно формувати поетапно. Відомо, що навички самоконтролю формуються передовсім у процесі взаємоперевірки, тому на першому етапі учні вчаться перевіряти роботи своїх однокласників (взаємоперевірка), знайшовши помилку, вказують на неї однокласнику, пояснюють іiі суть і як її виправити.

Наприклад, на уроці української мови в третьому класі під час вивчення теми «Загальне поняття про іменник. Іменники, що означають назви істот та назви неістот» на етапі сприймання й усвідомлення учнями нового навчального матеріалу можна запропонувати учням роботу в парах за варіантами. Учні I варіанту наводять приклади

С. I. О. Талаш, 2014. 
іменників, які відповідають на питання хто? Учні II варіанту наводять приклади іменників, які відповідають на питання щзо?

Після виконання завдання учні одержують таку інструкцію: обміняйтеся в парах зошитами. Перевірте правильність виконання завдання вашим однокласником. Якщо знайдете помилку, то поясність своєму товаришу суть помилки та як ії треба виправити.

На другому етапі завдання ускладнюється: учні після взаємоперевірки, знайшовши помилку в свого однокласника, не вказують на неї, а просять перевірити роботу самостійно, і допомагають 3 пошуком помилки лише в тому випадку, коли однокласник самостійно не впорався. Наприклад, на уроці української мови у третьому класі під час вивчення теми «Власні й загальні іменники. Велика буква у власних іменниках» на етапі осмислення нових знань у процесі практичної діяльності для роботи в парах учням пропонується чотири варіанти завдань на картках різного рівня складності. Пари обирають варіанти завдання, одержавши таку інструкцію: «Оберіть для виконання той варіант, з яким ви впевнені, що впораєтеся».

Картка 1. Дописати іменники, використовуючи подану довідку.

Ми живемо в місті_. Через місто протікає річка . Нам добре відомі історичні пам'ятки намого мicma: , а також пам'ятник

Слова для довідки: Інгулеиь, Козак Ріг, Кривий Ріг, човнова станиія.

Кратка 2. Виправити деформований текст. Підкреслити власні іменники однією рискою, а власні двома.

Нам завжди допомагає песик Дружок. Там у мене багато друзів. Я дуже люблю відпочивати у бабусі Ольги в селі Озерне. Але найбільше мені подобається разом із дідусем Павлом пасти корову Лиску.

Кратка 3. Складіть міні-оповідання, використовуючи такі слова: літо, відпочинок, Чорне море, вода, сонце, друг Сергій, Карпати. Підкресліть власні іменники.

Картка 4. Записати якнайбільше власних іменників, які починаються на букву $K$, загальних іменників на букву $M$ та $H$.

Після виконання завдань на картках учням дається така інструкція: обміняйтеся роботами, перевірте правильність їх виконання. Якщо знайдете помилки, то не виправляйте їх, а попросіть однокласника самому знайти помилку у своїй роботі та виправити іiі.

Зауважимо: для виконання цих завдань учитель формує пари 
гомогенного складу. Слід зазначити, що відсутність прямої вказівки на той варіант, який слід обрати, також сприяє формуванню навичок самоконтролю, адже спонукає учня самостійно оцінити складність кожного із запропонованих варіантів, об’єктивно оцінити власні сили, обрати той варіант, який відповідає своєму рівню. Якщо учень обирає варіант легший, ніж той, 3 якими міг би впоратися, то вчитель пропонує виконати самостійно відповідний рівню знань учня інший варіант. Якщо учень безпомилково виконує запропонований учителем варіант, то вчитель просить учня оцінити складність обох виконаних варіантів і зауважує, що наступного разу за обрання більш легкого варіанту буде зніматися один бал.

На третьому етапі, перш ніж передати свою роботу на перевірку однокласнику чи вчителю, учень повинен сам їі ретельно перевірити, адже якщо тепер після самоперевірки буде знайдено помилку, то зніматиметься бал. Наприклад, на уроці української мови в третьому класі під час вивчення теми «Закріплення навичок правопису загальних і власних іменників» на етапі виконання різних видів творчих вправ учням пропонується робота в малих групах.

І група. Записати, хто де живе.

У Болгарї- ...; у Польщуі - ...; в Італї - ...; в Естонії- ... .

II група. Записати, хто де живе.

Живуть іспанці в ..., франщузи в..., американці в ..., англійці в ....

III група. Продовжити речення.

В Украӥні проживають представники багатьох начіональностей - ие українці, .... .

IV група. Запишіть жителів міст.

В Умані - уманчани, в Києві - .., в Черкасах - .., у Львові - ..., у Кривому Розі - ... .

Після виконання завдання учням дається така інструкція: ретельно перевірте ще раз свою роботу, адже тепер за кожну пропущену вами помилку буде зніматися один бал. Після самоперевірки віддайте свою роботу однокласнику на перевірку. Підрахуйте кількість знятих балів кількість пропущених помилок.

На четвертому етапі учні вчаться перевіряти себе самостійно, звіряючись зі зразком. Наприклад, на уроці української мови у третьому класі під час вивчення теми «Рід іменників: чоловічий, жіночий, середній» на етапі осмислення нових знань у процесі практичної діяльності учням пропонується попрацювати в парах. Кожна пара 
одержує свою картку.

Картка 1. До поданих слів (слоненя, лисеня) дібрати спільнокореневі іменники чоловічого, жіночого, середнього роду. Записати за зразком. Виділити корінь, визначити рід.

Зразок: ведмежа - ведмідь (ч. р.) - ведмедиия (ж. р.) - ведмежсатко (с. р.).

Картка 2. До поданих слів (вовченя, тигреня) дібрати спільнокореневі іменники чоловічого, жіночого, середнього роду. Записати за зразком. Виділити корінь, визначити рід.

Зразок: ведмежа - ведмідь (ч. р.) - ведмедиця (ж. р.) - ведмежатко (с. р.).

Кратка 3. До поданих слів (каченя, гусеня) дібрати спільнокореневі іменники чоловічого, жіночого, середнього роду. Записати за зразком. Виділити корінь, визначити рід.

Зразок: ведмежа - ведмідь (ч. р.) - ведмедиия (ж. р.) - ведмежсатко (с. р.).

Після того, як учні закінчили виконувати завдання, вони перевіряють свої роботи, потім учитель відкриває на дошці правильно виконані завдання і просить ще раз себе перевірити. Після цього вчитель бере на перевірку кілька зошитів, за кожну пропущену помилку знімає бал.

Отже, групова навчальна діяльність створює оптимальні умови для формування навичок самоконтролю, адже за цієї форми роботи учня працюють максимально самостійно, тому кожен етап роботи повинні контролювати. Навички самоконтролю - це складні утворення, тому мають формуватися поетапно, цілеспрямовано й систематично. У подальшому, на нашу думку, доцільно розглянути особливості формування навичок самоконтролю молодших школярів на різних етапах уроку в процесі використання інших форм роботи.

\section{Література}

1. Боришевський М. Виховання самоконтролю в учнів початкових класів / М. Боришевський. - К., 2000. - С. 19-140.

2. Нор Е. Технология организации групповой учебной деятельности / Е. Нор. Николаев, 1998. - С. 5-75.

3. Савченко О. Я. Дидактика початкової освіти : [підручник] / О. Я. Савченко. - К. : Грамота, 2012. $-504 \mathrm{c}$.

4. Сердюк А. Психологические особенности воспитания самоконтроля у учащихся 1-3 классов в учебной работе / А. Сердюк. - К. - С. 23-245.

5. Танцоров С. Организация групповой работы. Групповая работа в развивающем образовании : [монография] / С. Танцоров. - Рига, 1997. - С. 19-35.

Стаття надійшла до редакиії 16.09.2014 p. 